\title{
The impact of maritime transport financing on total trade in South Africa
}

\author{
W. Matekenya ${ }^{*}$ (I) and R. Ncwadi
}

\section{${ }^{*}$ Correspondence:}

Weliswa.

matekenya@mandela.ac.za

Department of Economics,

Nelson Mandela University,

Port Elizabeth, South Africa

\begin{abstract}
The study explored the impact of maritime transport financing on trade in South Africa. Using the Autoregressive Distribution lag model, we examine the impact of maritime transport financing on total trade in South Africa during the period 1994 to 2019. The results confirm a long and short-run positive relationship between maritime transport financing and total trade. The findings suggest an overall, substantial investment in maritime transport has the potential to promote trade flows in South Africa. We recommend more investments towards maritime transport infrastructure to ensure a significant increase in exports, and to stimulate economic development in South Africa.
\end{abstract}

Keywords: Maritime transport, Trade, ARDL, Financing

JEL Classification: F14, L92, H54

\section{Introduction and background}

According to the Department of Environmental Affairs (DEA) (2019), maritime transport (ocean transport) refers to the transportation of people and goods via sea routes. The Maritime Transport Sector consists of a national registry, flagging, and cargo handling whereas while maritime manufacturing has to do with the building of marine vessels, rig and ship repair, and includes offshore oil and gas services. Maritime Transport has a system that is integrated which includes the design, construction, operation, management, servicing, and maintenance of merchant, leisure, and other ships in the service of seaborne trade. It also involves the conducting of offshore operations, port construction, shipbuilding, maritime services, and the transporting of people and cargo from point A to B by sea or via inland waterways. In addition, effective domestic demand and employment, which make a great contribution to a country's economic development (Walker 2018; Shi and Li (2016); .

According to Stopford (1997) during the1960s maritime transport began, on a global scale, primarily using containers for large loads of cargo, and found these to be a useful and cost-effective cargo transportation mode over any distance by large boats or ships, and over oceans and lakes. This transport mode has since proved to be the most popular among people and companies engaged in international trade. However, while it is the least expensive and relatively environmentally friendly option, it is also the most

(c) The Author(s) 2022. Open Access This article is licensed under a Creative Commons Attribution 4.0 International License, which permits use, sharing, adaptation, distribution and reproduction in any medium or format, as long as you give appropriate credit to the original author(s) and the source, provide a link to the Creative Commons licence, and indicate if changes were made. The images or other third party material in this article are included in the article's Creative Commons licence, unless indicated otherwise in a credit line to the material. If material is not included in the article's Creative Commons licence and your intended use is not permitted by statutory regulation or exceeds the permitted use, you will need to obtain permission directly from the copyright holder. To view a copy of this licence, visit http:// creativecommons.org/licenses/by/4.0/. 
time-consuming one. Its benefits also include transportation of large volumes of goods with low costs and the most used in modern societies.

According to the United Nations Conference on Trade and Development (UNCTAD) of 2019, maritime transport remains the backbone of global trade and manufacturing supply chains. UNCTAD (2019) reports that more than a quarter of world trade volume is done via ocean transport. Further, maritime transport handles 80 percent of trade by volume with approximately 70 percent of its value (UNCTAD 2019). According to the NCTAD report 2019, this trade has been linking global economics and has acted as a critical enabler of trade, an engine of growth, and a driver of social development (UNCTAD 2019). According to Rodrigue (2020) over centuries, maritime transport has played a major role in trade. Apart from representing a co-dependence between trade, shipping services, and the supply chain, it has generated measurable social and economic gains. Further, it also plays a vital role in bringing together maritime transport providers and users, and all the parties in the international supply chain to work together for the benefit and profitability of a trade.

Maritime transport is not only faced with rapid growth in demand and pressure from transport services, but also technical challenges which include outdated infrastructure which results in congestion and causes delays. Further, this includes a lack of investment for upgrading and maintaining ports infrastructure [Department of Environmental Affairs (DEA 2019)]. In addition according to Operation Phakisa (2015), marine transport and manufacturing in South Africa are challenged by outdated, insufficient, and expensive infrastructure, lack of skills, limited support for market growth from public procurement, and limited support for a national ship registry or flagging of South Africa ship which hinders growth in the industry. These challenges in the maritime sector have increased a need to be addressed because the sector is crucial in the economic development of South Africa. Traditionally, the public sector plays a key role in financing maritime transport infrastructure, however, public sector investment is not enough to cater to the growing finance gap in maritime transport. To ensure consistent growth demand and ensure proper services delivery mobilizing public and private is necessary which also includes FDI, development aid to participate in a partnership.

South Africa is a primary goods export-oriented economy. The total cost of importing foreign-produced products and delivering their agricultural produce, minerals, and other industrial outputs to foreign markets is impacted significantly by the transportation element. Transport is a significant trade input cost due to our distant location from the markets that we serve. There is therefore the need to strive for national transport cost efficiencies to remain globally competitive as a country. Although this validates South Africa as a maritime trading nation, it is, however, not yet a significant ship owning or ship operating nation. It is currently a consumer of international maritime transport and hence this component represents a significant expense item for South Africa's international trading system. This creates an economic imbalance, which if not addressed, will continue to facilitate the loss of much-needed revenue, economic opportunities, and related jobs for South Africa and the South African Maritime Transport Sector. The ability of South Africa to carry its import and export trade has suffered a negative growth since the 1980s. South Africa does not have a national shipping carrier. This sector has the potential to offer significant employment opportunities for thousands 
of South Africans across the diverse expertise required in the various disciplines of the sector that include marine manufacturing and related services, seafaring, maritime law, research, marine engineering, etc.

Currently, the Maritime Transport Sector in South Africa has the potential to become a high-impact sector and one which could offer a substantial contribution to addressing developmental challenges in South Africa and fulfilling the goals of the National Development Plan (NDP). Despite its importance to the country's economic development, the Maritime Transport Sector in South Africa is still in the process of developing the necessary instruments and infrastructure to expand and to come to play an essential role in South Africa's economic development. This specific development goal, the revival of the Maritime Transport Sector, and the improvement of its contribution to the growth and radical transformation of the South African economy. Therefore, the development of the sector which includes reviving and promoting it should be highlighted to the broader agenda of contributing towards the global competitiveness of the country as a maritime leading nation (DEA 2019).

To date in South Africa, the government has played a key role in financing maritime transport infrastructure. However, public-sector investment is not enough to cater to the growing financial shortfall in the maritime transport sector, due partly to its decline, as mentioned above. To ensure consistent growth demand and proper service delivery of maritime transport, the mobilization of both the public and private sectors is necessary. This includes the participation of foreign direct investment (FDI) and development in partnership.

A review of the existing literature has shown other studies to have investigated the impact of port infrastructure and trade or economic growth (Ismail and Mahyideen 2015; Kazutomo and Wilson 2019; Jouili and Allouche 2016; Igberi and Ogunniyi 2013) and whilst other literature focus on the impact of investing on port infrastructure and international trade and economic growth and few studies that focused on marine transport and international trade. There is limited literature on marine transport in the South Africa context and more especial that focusing on investing in maritime transport. Therefore, this study examines the impact of maritime transport financing on total trade in South Africa using the autoregressive distributed lag (ARDL) model. In this instance, this study fills a gap in the existing literature in the sense that a large number of studies in this area used models of analysis such as structural equation modeling (SEM), Generalised Method of Moments (GMM), and pooled mean group (PMG) estimator. None of these studies have attempted the use of ARDL.

The paper is organized into six sections: the first section is introduction and background, followed by an overview of marine transport financing and trade in South Africa, literature review which includes theoretical and empirical review, outlines the methodology, indicating the variables used in the analysis, and describing the econometric model, analysis and discussion of results and the last part is conclusion and recommendations.

\section{Overview of total trade and maritime transport financing in South Africa}

According to Funke et al. (2016), South Africa's coastline is about $3924 \mathrm{~km}$ of and a total sea-land exceeds the total ears of the country's land size. Approximately, 30 percent 
of the population in South Africa lives around the coast. The position of the country is around on a major shipping route and has eight commercial ports and 44 non-commercial harbours. South Africa's trade to GDP ratio for 2019 was 59.20 percent, while imports and exports at the time were approximately 60 percent of South African Goss Domestic Product (GDP) (UNCTAD 2019). This is an indication of the extent to which the South African economy is dependent on trade. South Africa is not close to its trading partners or markets, however, it concentrated on a major sea trading route that connects American and Asian markets. The maritime interest of South Africa originates from its geo-economic structure and trade (Ntuli 2017). It is for these reasons that, as has already been mentioned, the maritime transport sector has the potential to contribute significantly to economic development.

The ninth Sustainable Development Goal (SDG target 9) highlights the critical trends in maritime transport infrastructure and services that underpin trade, supply chain linkages, and economic integration. According to DEA (2019), investing in maritime transport is the critical vein feeding the blood circulation system of South African economic development. Most of South Africa's trade is characterized by seaborne and moves within a system of commercial ports of the country. As has been mentioned, in South Africa, seaborne trade is estimated to account for between 80 and 90 percent of the economy South African maritime transport owes its evolution to the development of international trade and the ever-growing exchange of goods between countries (Shi and Li 2017).

In 1994 the total trade rate was approximately 40 percent, and the trade policy regime that was adopted at that time by the democratic government began the transformation of the South African economy. This resulted in a dramatic expansion of trade to expand over the period 1994 to 2001, from 40 to 59 percent (Edwards and Schoer 2002). According to World Trade Organisation (2019) during 2019 South African exported USD 90 Billion while importing USD 107 Billion of goods and it shows an increase in the volume of exports and imports. Further, its export services are valued at USD 14.3 billion and while imports services are valued at 15.3 USD billion. Therefore, the country has a recorded trade surplus valued at USD1.7 billion.

The Maritime Transport Sector is one of the key economic sectors instrumental in the future unlocking of the country's ocean economy to promote growth in the economy (Ntuli 2017). As has been mentioned, it is one of the means of achieving the objectives outlined in the 2011-2030 National Development Plan (NDP) and the New Growth Path (NGP). According to Morapedi and Makhhari (2017)) have highlighted that the National Transport Master Plan (NTMP), has strategies to deal with challenges that affect infrastructure on maritime transport to meet 2030 targets goals.

Operation Phakisa's first focus area relates to the maritime development of the South African economy. Operation Phakisa is the governmental programme that was incepted in July 2014 to fast-tracking National Development Plan (NDP) 2030 vision and to address constraints in public service delivery. Operation Phakisa identified the maritime sector as one of the other priorities for the Ocean economy (Operation Phakisa 2015). According to Veitch (2017) improving maritime transport sector infrastructure will continue to approximately contribute R56.5 billion to South African economic growth. The maritime initiative under Operation Phakisa was planned to take South Africa to 
5\% growth by 2019 (DEA 2019). In order to examine the relationship between maritime transport financing and total trade, a graphical presentation was presented in Fig. 1. Figure 1 shows trends between the two variables of interest.

Figure 1 shows the annual trends of both total trades as a percentage of GDP and percentage change of government expenditure on maritime transport and manufacturing from 1994 to 2019. In the late 1990s, both graphs depict an upward trend which shows there is a positive relationship between the total trade and government expenditure on maritime transport and manufacturing. During the period of 1997/98 to 2003/04, government expenditure for marine transport has increased by 6.6 percent (National treasury 1999). While trade policy regime was adopted transformed the economy by increasing total trade significantly from 1994 to 2001 from 40 to 59 percent (Edwards and Schoer 2002).

During early 2000 to 2006 government expenditure did not increase much, however, total trade was still performing very well which show an upper trend from early 2000 to 2004 and there was slight drop but started to pick up again up until the global financial crisis in 2008. The global financial crisis affected both and the trends were declining. During the period of 2008/09 to 2011/12 expenditure in this programme declined from R74.3 million to R67.1 million respectively (National treasury 2011). However, during the period of 2008, the global financial crisis which hit 2008 to 2009 decreased the total trade by 24 percent (International Monetary Fund 2016). Although, in 2010 South Africa's total trade witnessed a recovery trend whereby there was a growth of 17 percent in 2010 (Taku Fundira 2011).

In 2019, South Africa approximately exported a total of $\$ 10$ billion, which made South Africa be number 36 exporter in the world. This was the growth from $\$ 103$ billion in 2014 to $\$ 109$ billion in 2019. While the imports decreased from $\$ 106$ billion in 2014 to $\$ 88.5$ billion in 2019 (World Trade Organisation 2019). During the period of 2016/17 to $2018 / 19$, the departmental budget will increase with approximately R56.3 billion to

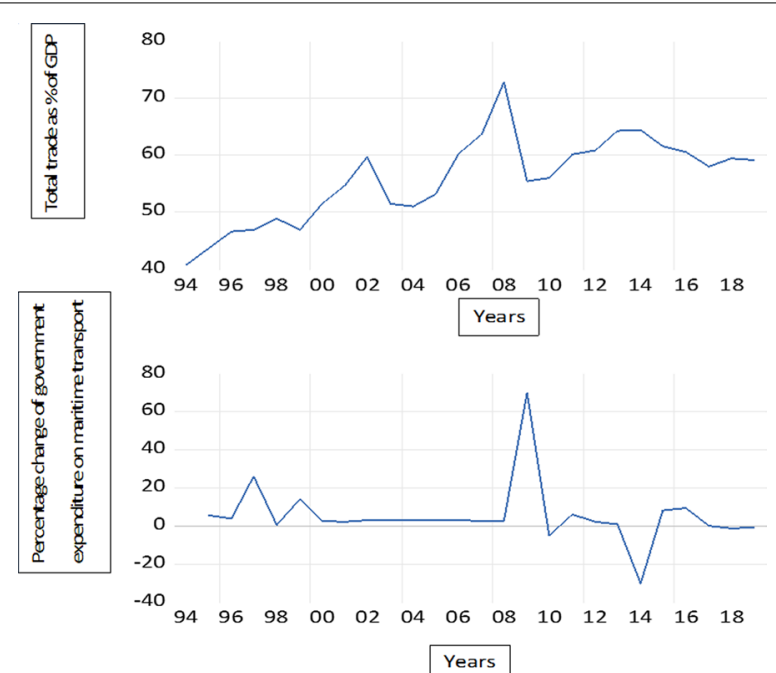

Fig. 1 Trends of total trade and maritime transport financing from 1994-2019. Source: World bank 2020 and National treasury, 2020 
R68.6 billion respectively and this includes R15.9 million to support the operations of maritime transports, R19 million for strengthening the regulatory capacity of ports regulator (National Treasury 2017).

\section{Literature review}

This section presents a review of the available literature on the relationship between marine transport financing and total trade. The section is divided into two subsections, the theoretical framework literature, and the empirical literature. The theoretical literature is drawn from theories on the relationship of investment on infrastructure on the total.

\section{Theoretical literature review}

The Neoclassical economic framework explains the impact of investment on seaport infrastructure (Lakshmanan 2011). Where the theory assumes that investment is an exogenous factor that plays a vital role in seaport infrastructure quality by improving it. Therefore, better seaport infrastructure improves logistics performance in the international trade of the country, and which will expand markets worldwide by providing opportunities both local and international or globally.

According to Limao and Venable (2001), Nordas and Piermartini (2004) and Clark et al (2004a, b) have shown increasing evidence of investment in seaport infrastructure quality on international trade. Where the literature has suggested that investing in seaport infrastructure plays an important role in reducing trade costs. Trade cost includes transport cost, tariffs, and cost of days and uncertainties of shipment deliveries (Nordas and Piemartini 2004). Therefore, the seaport investment reduces all the trade cost and increase trade. According to Yeaple and Golub (2002) investing in seaport infrastructure also explain the absolute and comparative advantage of countries on the effect of total factor productivities. Therefore, specialization in international trade does not only depend on factor endowments but-increasingly on the quality of public infrastructure provision.

Bougheas et al. (1997) developed a gravity model that explains the influence of transport cost on the relationship of quality infrastructure on trade. In addition, transport costs are assumed to be barriers to trade, which discourage trade activities. Therefore, investment in infrastructure reduces those trade barriers. Investing in Infrastructure has a positive influence on trade volume, and it reduces the transport cost. The model estimate that trade flows are influenced by economic size and distance between units. Further, Engen and Hubbard (2004) explains the impact of transport costs on trade. Where he treated transportation under the category of services that need to be consumed for international trade to take place. These transport costs could be financed in a variety of ways including government expenditure on infrastructure.

Therefore, this gain in international trade will also improve opportunities in terms of production expansion and labour supply and demand. The benefits of investing in seaport infrastructure are not limited to travel-time saving (Banister and Berechman 2001). Lakshmanan (2011) showed that improved freight services lead to growing trade, followed by improved labor supply and technical diffusion. The quality of the infrastructure and the services it provides seem to be as important as a determinant of a country's 
ability to trade with the rest of the world, one that should be included when analysing the impact of infrastructure investment. Further, the public sector has made an intensive investment into seaports infrastructure which includes improving ports and developing new ports. In the modern days, ports play an important role on only in cargo handling but also in the provision of better logistics services in order to meet the increasing demand and global supply chain (Hausman et al. 2013).

The broad literature that uses the gravity approach to the study of international bilateral trade shows that geographical distance, and therefore transport cost, is negatively related to trade. Similarly, Limao and Venable (2001) highlighted that the increase in transport costs affects trade flows negatively. Therefore, poor infrastructure reflects the existence of increased transport costs.

Further, investments in seaport infrastructure create a better business environment and improve transport efficiency, which facilitates export growth (Portugal-Perez and Wilson 2012). Yeo et al. (2008) found that quality of port service, logistics costs, regional connectivity, hinterland condition, and port accessibility, contribute significantly to a port's competitiveness. Gordon et al. (2005) added that a combination of port facilities, including sufficient investment, supportive government policies, excellence in operation, and information technology, can help a port attain sustainable competitiveness, which will produce higher seaborne trade compared to the less competitive ports.

According to the New trade theory, which was developed by Falvey (1976) highlighted an increase in trade flow or factor mobility has caused a raising level of interdependence among countries. This is where the transport cost factor plays an important role in integrating the countries. Therefore, poor infrastructure also acts as a barrier to trade flow and the quality and effectiveness of it has a positive relationship with economic activities. It is already mentioned that investing in infrastructure has a positive influence on trade because it reduces transport or shipping cost. This theory highlights the importance of transport cost influencing the cross-country trade and movement of factors of production.

\section{Empirical literature review}

According to Loon (2009) the realization by governments, economists, and policymakers that maritime transportation plays and has a potential role to play in the economic development of any nation and has resulted in the industry gaining a lot of attention. In addition, is essential to the functioning not only of modern society and social systems, but particularly of the global economy, and interdependence. Maritime transport is an important component of the transportation system, and it accounts for a large part of world trade. Given the great importance of marine infrastructure that has been discussed in the literature in the past decade many papers have been published more especial on the port's infrastructure investment around the globe. However, South Africa contributes very little to that literature.

The majority of the literature review highlights discussion around the impact's ports and logistics performance on international trade and economic growth, emphasizing the importance of investing in port infrastructure for economic growth and international trade. For instance, Jiang (2010) explores the investment in seaport and economic development in China and Korea. The results show that there is a positive 
relationship between seaport investment on economic growth. These results are also supported by Song and Geenhuizen (2014) who found a positive relationship on regional growth. Therefore, seaport cargo throughput has a significant impact on the host country's economic growth. Similarly, Hargono et al. (2013) found a positive relationship between seaports exports and imports and economic growth.

Deng et al. (2013) explored the relationship between ports and the regional economy in major cities in China. The study employed SEM to estimate the results. The results of the study show that port activities have a positive relationship with the regional economy while port demand and supply did not have a significant relationship with the regional economy. These results suggest that a port city wishing to accelerate the development of the regional economy needs to take account of the acceleration of the total volume of imports and exports. Similarly, a study by Bottasso et al (2014) who also find the existence of the positive relationship of seaport activity on regional GDP confirms the opportunity for further investment in the port's infrastructure development.

Ismail and Mahyideen (2015) examined the relationship of the quality of port infrastructure on trade flows in some Asian countries. Their results showed a measurable increase in trade flows from improvements to transport infrastructure in these countries. Similar results were obtained from the study by Helble (2014) who found transport infrastructure quality has positively affected trade flows and is statistically significant. Such studies indicate infrastructure to be vital to the economic development of a country, being key to achieving low trade costs, thus increasing the trade value and volume for a country. According to World Economic Forum (2015), highlighted that quality infrastructure not only reduces the distance between regions but also integrates national markets and connects them at low costs to other economies.

Park and Seo (2016) assessed the impact of seaports on the regional economy using panel data on panel data covering all the regions of Korea over the period 2000 to 2013. The results show that cargo ports without sufficient throughput hinder regional economic growth while cargo ports with sufficient throughput contribute to economic growth. Therefore, port activities positively affect regional economic growth, while port investment indirectly leads to economic growth. It implies that the port investment positively affects both cargo and container throughput. In turn, those throughputs may contribute to the regional economy. Similarly, Han et al. (2019) also found that port efficiency has a great influence on economic regions of Beijing Tianjin Hebei (BTH) region from 1996 to 2015, and therefore investment in port efficiency plays a major role in the economic development of that region.

Munim and Schramm (2018) analysed the impact of port infrastructure quality and logistics performance from 91 countries on seaborne trade. An SEM is used to provide empirical evidence. The countries were divided into developing and developed groups. The results show that it is important for developing countries to continuously improve their port infrastructure in order to promote seaborne trade and economic growth. However, this relationship weakens as the developing countries become richer. Therefore, the improvement of port infrastructure would benefit the country's economy. The quality of port infrastructure has a significant positive relationship with economic growth. The results of the study are also supported by Ferrari et al. (2010). 
Kazutomo and Wilson (2019) examined the impact of port infrastructure on exports and imports of emerging economies in East Asia. The results of the study show that port congestion increased transport costs. Therefore, results also suggest that a significant amount of investment has a positive relationship with exports and it also reduces transport costs Similarly, Gani (2017) where he examines the quality of logistic performance on exports and imports. Further the results show that better quality of logistics performance has a positive relationship with exports and imports. Further, Sakyi and Immurana (2021) also assessed the seaport efficiency on total trade in the sample 27 countries in Africa from the period of 2010 to 2017. The study employed the aid of the dynamic system GMM estimation technique. The results of the study show seaports efficiency increase the trade balance in both the long and short run. Therefore, it is imperative to enhance seaport efficiency in Africa.

While other studies were focusing on the impact of investment on port infrastructure and international trade and economic growth. Jouili and Allouche (2016) assessed the impact of seaports investment on the economic growth in Tunisia from 1983 to 2011. This study used an econometric model by employing the Cobb-Douglas production function. The results of the study show that the public investment in seaport infrastructures has a positive influence on Tunisian economic growth. The study also revealed that the biggest beneficiary of the seaport investment infrastructure is the service sector. These results are similar to those from studies conducted in Nigeria by Igberi and Ogunniyi (2013) and by Lloyd et al. (2020) both of which studies showed maritime transport to have positive and significant impacts on the economic growth of that country.

Song and Van Geenhuizen (2014) assessed the relationship of port infrastructure investment on the regional economic growth of China from the period of 1999 to 2010. The results indicated a clear positive relationship of port infrastructure investment in all regions. They may conclude that port infrastructure investment has a positive impact on regional economic growth in China, but with obvious differences at the regional and provincial levels. Contrary Chang et al. (2014) assess the economic impact of ports in the South African economy with input-output analysis. These results show that fewer port activities have a negative relationship with economic growth. If there were no port sector activities, it would have resulted in an R1.481 billion direct loss to the entire economy. Similarly, the study by Fedorenko et al. (2021) explores the impact of port investment on trade in the sample of five Russian regions from the period 2010 to 2019. The study makes use of regression analysis using panel data and nonlinear models. The results of the study show that investing in seaports promotes foreign trade growth in the host region and neighbouring regions. While the cost of environmental has a negative relationship between the volume of exports and imports.

There are very few studies that focused on marine transport investment or infrastructure on international trade. Rehman et al. (2020) examined the short- and long-run impact of infrastructure-of transport and other sectors-on export and trade deficit in selected South Asian countries during the period 1990 to 2017. The study made use of PMG estimator and cointegration techniques, such as the Pedroni and Kao test, as methodology. The results show infrastructure to be positively related to, and/or to promote exports, while there is a negative relation between infrastructure and trade deficit. Based on the results of their study indicating, that in the long run the quality of 
infrastructure promotes exports and decreases trade deficit, the authors recommended a focus on generally enhancing the quality and efficiency of infrastructure.

Mudronja et al. (2020) assess the relationship of seaports on economic regional growth for the sample of 107 European Union's (EU) port regions and over the period from 2005 to 2015. The study makes use of GMM dynamic panel data analysis. The results show that the operation of seaports has a positive impact on the economic growth of their regions. While investment in transport infrastructure has a negative impact on economic growth and is statistically insignificant. One of the reasons for this may be that the relationship of investing in transport infrastructure can only be seen after several years. This can also be justified by the fact that if there is a developed economy, there will already be quality infrastructure in place. This means that quality infrastructure is a consequence of a developed economy and not the other way around whereby infrastructure is the driver of the economy.

Akbulaev et al. (2020) assess the relationship between maritime transport and economic growth in the following countries Russia, Azerbaijan, Turkmenistan, Kazakhstan, and Iran. The study uses the SWOT-analysis and correlation analysis methodology to estimate results which show that a positive relationship to economic growth. These results are similar to the study that was done by Tayebi et al. (2015) using GMM, and a survey to estimate the impact of maritime transport on economic growth in Iran from the period 1996 to 2012. The results show that there is a positive relationship on the economic growth, there increasing investment in maritime transport is advisable based on the results of the study. Similarly, Fratila et al. (2021) examine the relationship of maritime transport on economic growth in the EU counties using the panel data from 2007 to 2018. Therefore, a panel regression model was used to estimate results that show that investment in maritime infrastructure has a positive relationships on economic growth. However, the existence of environmental issues hinders growth in the sector.

In the South Africa context to date, not much research has been done to investigate the impact of marine transport financing on international trade in South Africa and some studies were too limited to explore the various method of contribution or assessing the impact of marine transport financing to economic growth and other economic indicators while other studies are based on estimates. Then study attempts to contribute towards exploring the impact of marine transport on total trade in South Africa and also contributing to the body of literature on the subject.

\section{Data and methodology}

This section presents the data and outlines the methodological approach of the study. Due to data limitations, the study utilised annual data from 1994 to 2019. The Autoregressive Distributive Lag (ARDL) technique (discussed below) was used to estimate the short-run and long-run relationship employed for the empirical analysis. The study employs a time series analysis using data from the period 1994 to 2019. Table 1 shows the description of the data and the sources of the data, including the discussion and the justification of variables.

The empirical model for the TRADE Maritime transport financing nexus is specified as follows: 
Table 1 Data description

\begin{tabular}{|c|c|c|}
\hline Variable & Description & Source \\
\hline MTF & $\begin{array}{l}\text { Maritime transport financing refers to government expenditure } \\
\text { on Maritime transport which is measured in millions. This can } \\
\text { be increased or decreased on the capital expenditure and can } \\
\text { affect total trade either positively or negatively }\end{array}$ & National Treasury \\
\hline TRADE & Total trade as a percentage of GDP (export plus imports) & World Bank \\
\hline BUSINESS FREEDOM & $\begin{array}{l}\text { An overall indicator of the efficiency of government regulation } \\
\text { of business. The ease of doing business can promote trade } \\
\text { flows (Depken and Sonora 2005) }\end{array}$ & Heritage foundation \\
\hline GOVERNMENT INTEGRITY & $\begin{array}{l}\text { A trustworthy government is free from corruption and able to } \\
\text { fulfill its commitment to protecting the interests of inves- } \\
\text { tors. Government corruption undermines public expenditure } \\
\text { (Qiongzhi and Qi 2011) }\end{array}$ & Heritage foundation \\
\hline LENDING RATE & $\begin{array}{l}\text { The rate of interest that is paid on a loan. A high rate of interest } \\
\text { affects the trade balance. Lower interest rates increase exports } \\
\text { (Batra and Beladi 2013) }\end{array}$ & World Bank \\
\hline
\end{tabular}

$$
T R A D E_{t}=\beta_{0}+\beta_{1} M T F_{t}+\beta_{2} B F_{t}+\beta_{3} G I_{t}+\beta_{4} L R_{t}+\beta_{5} F C_{t}+\beta_{6} O P_{t}+\mu_{t}
$$

where $M T F_{t}$ is the government capital expenditure on Maritime transport. $B F$ is the business freedom in South Africa. $G I_{t}$ is government integrity. $L R_{t}$ is lending rate. FC is a dummy for the financial crisis ( 1 is for the years 2008 and 2009 when there was a financial crisis and 0 for the other years). OP is a dummy for Operation Phakisa ( 1 for the period operation Phakisa was incepted 2014 to 2019. and 0 for other years). $\mu_{t}$ is the error term. This represents other factors that affect the trade that is not included in the model.

Where $\beta o, \beta 1$, are coefficients of the explanatory variables, $t$ represents time series and $\mu$ is the error term. The error term represents the influence of the omitted variables in the study.

\section{Empirical results}

Table 2 shows the descriptive statistics. There is a significant difference between the minimum and the maximum value. Trade has a high mean value of 55.85 percent, with a high standard deviation of 7.48 percent and positive Kurtosis of 2.64 percent indicating high peak distribution and negative Skewness of -0.07 percent. Maritime transport financial has the highest mean value and the largest standard deviation with low kurtosis of 1.74 percent which indicates low peak distribution and positive Skewness (Table 3).

Unit root tests are conducted to determine the order of integration of the different variables. The ARDL technique may be employed in the presence of variables of different orders of integration. Further, the ARDL cointegration technique is preferable when dealing with variables that are integrated of a different order, I(0), I(1), or a combination of both., It is robust when there is a single long-run relationship between the underlying variables in a small sample size. The study employed unit root tests such as the Augmented Dickey-Fuller test proposed by Dickey and Fuller (1981), Phillips and Perron (1988) test, and the DF-GLS unit root test developed by Elliott et al. (1996). Table 4 presents the unit roots tests. The overall unit test results show that all variables are integrated of order one i.e. I(1) and in all three-unit roots tests. 
Table 2 Descriptive statistics

\begin{tabular}{llllll}
\hline Variable & TRADE & MTF & B_FRE-EDOM & G_INTEGRITY & L_RATE \\
\hline Mean & 55.85 & $92,273,212$ & 74.10 & 47.41 & 13.09 \\
Median & 56.98 & $80,684,786$ & 72.30 & 47.60 & 11.50 \\
Maximum & 72.86 & $1.47 \mathrm{E}+08$ & 85.00 & 57.00 & 21.79 \\
Minimum & 40.76 & $41,659,000$ & 62.00 & 39.70 & 8.50 \\
SD & 7.48 & $34,328,394$ & 6.99 & 4.29 & 3.89 \\
Skewness & -0.07 & 0.259903 & 0.47 & 0.29 & 0.70 \\
Kurtosis & 2.64 & 1.745367 & 2.24 & 2.84 & 2.33 \\
Jargue-Bera & 0.16 & 1.997995 & 1.52 & 0.38 & 2.60 \\
Probability & 0.92 & 0.368248 & 0.46 & 0.82 & 0.27 \\
Sum & 1452.11 & $2.40 \mathrm{E}+09$ & 1852.60 & 1185.30 & 340.52 \\
Sum sq. dev. & 1401.04 & $2.95 \mathrm{E}+16$ & 1175.31 & 443.12 & 378.90 \\
Observation & 26 & 26 & 26 & 26 & 26 \\
\hline
\end{tabular}

Table 3 Unit root tests

\begin{tabular}{|c|c|c|c|c|c|c|}
\hline \multirow[t]{2}{*}{ Variable } & \multicolumn{2}{|l|}{$\mathrm{ADF}$} & \multicolumn{2}{|l|}{ PP } & \multicolumn{2}{|c|}{ GF-GLS } \\
\hline & Level & 1st diff & Level & 1st diff & Level & 1st diff \\
\hline TRADE & -2.89 & $-5.23^{* * *}$ & -2.91 & $-8.99^{* *}$ & -2.99 & $-5.62^{* * *}$ \\
\hline MTF & -2.03 & $-5.37^{* * *}$ & -2.05 & $-5.38^{* *}$ & -2.19 & $-5.61^{* * *}$ \\
\hline B_FRD & -1.99 & $-4.83^{* * *}$ & -1.99 & $-4.83^{* * *}$ & -2.06 & $-5.06^{* * *}$ \\
\hline G_CRS & -3.27 & $-4.44^{* * *}$ & -3.15 & $-4.39^{* * *}$ & -3.43 & $-4.66^{* * *}$ \\
\hline L_RATE & -3.30 & $-4.50^{* * *}$ & -2.37 & $-4.51^{* * *}$ & -3.39 & $-4.22^{* *}$ \\
\hline
\end{tabular}

Sources: Authors' own computation using data from World bank, National Treasury, and Heritage Foundation

** and ${ }^{* * *}$ indicate significance at the $10 \%$, and $5 \%$ levels respectively

Table 4 ARDL Bounds test

\begin{tabular}{|c|c|c|c|c|}
\hline Dependent variable & $\begin{array}{l}\text { F-stats } \\
\text { MTF }\end{array}$ & $1 \%$ & $5 \%$ & $10 \%$ \\
\hline TRADE & 4.248 & Cointegration & Cointegration & Cointegration \\
\hline Level of significance & & Lower I (0) & & Upper I (1) \\
\hline \multicolumn{5}{|l|}{ Critical values } \\
\hline $1 \%$ & & 3.74 & & 5.06 \\
\hline $5 \%$ & & 2.86 & & 4.01 \\
\hline $10 \%$ & & 2.45 & & 3.52 \\
\hline
\end{tabular}

Diagnostic tests were performed on the estimated models, such as the (Breusch 1978; Godfrey 1978) LM tests for autocorrelation, the (Breusch and Pagan 1979) test for heteroscedasticity, the (Jarque and Bera 1980) normality test, and the (Ramsey 1969) RESET test for model specification.

The results for the bounds test in Table 4 reveal that there is a long-run relationship among the variable's interests. The f-statistics number is greater than the upper 
bound critical value at a 5 percent level of significance, which means that the null hypothesis of no cointegration is rejected.

Table 5 shows the long-run and short-run results of the model. Investing in Maritime transport has a positive and statistically significant relationship with total trade in South Africa both the long and short-run analyses. The study by Rehman et al. (2020) and that done by Operation Phakisa (2015), examine the impact of transport infrastructure on trade and have also found this infrastructure to have a positive relationship with total trade. This shows that investing in maritime transport promotes exports, or trade flows, and contributes to higher volumes of seaborne trade. Therefore, these results are consistent with a theoretical and empirical literature review that investing in transport infrastructure promotes trade flows.

Business freedom has been shown to have a positive and statistically significant relationship with total trade. While government integrity, lending rates, and financial crises are negatively and significantly affecting total trade. Operation Phakisa has a positive and statistically insignificant relationship with the total trade in South Africa. Operation Phakisa is measuring the period during the inception of Operation Phakisa. Further, analysis of the trend of total trade during this period of inception shows total trade in South Africa to have experienced a downward trend. Thus, the statistical insignificance could not be explained by the period of the inception of Operation Phakisa.

The results of the analysis suggest that total trade in South Africa is most affected by investment in maritime trade and that this is due to maritime transport being the backbone of global trade and the manufacturing value chain. This is the evidence that shows that more than a quarter of world trade volume is done via sea. Further, during the 1994-2019 period maritime transport handled $80 \%$ of trade by volume, with approximately 70 percent of its value. In other words, maritime transport has been

Table 5 Long and short-run

\begin{tabular}{lcccc}
\hline Variable & Coefficient & Std error & t-statistic & Prob \\
\hline Longrun & & & & \\
C & $-754.09^{* * *}$ & 248.91 & -3.02 & 0.00 \\
LOG(MTF) & $44.30^{* * *}$ & 11.48 & 3.85 & 0.00 \\
BUS_FREEDOM & 0.47 & 0.30 & 1.54 & 0.14 \\
LGOV_INTEGRITY & -4.41 & 22.15 & -0.19 & 0.84 \\
LENDING_RATE & -0.48 & 0.85 & -0.56 & 0.58 \\
F_CRISIS & $-28.06^{* * *}$ & 8.99 & -3.12 & 0.00 \\
OP & 7.11 & 4.77 & 1.49 & 0.15 \\
Shortrun & & & 1.79 & 0.09 \\
DLOG(MTF) & $16.22^{*}$ & 9.71 & 1.71 & 0.10 \\
D(BUS_FREEDOM) & $0.29^{*}$ & 0.16 & -0.19 & 0.84 \\
D(LGOV_INTEGRITY) & -2.67 & 13.55 & 2.89 & 0.01 \\
D(LENDING_RATE) & $1.37^{* * *}$ & 0.47 & -3.48 & 0.00 \\
D(F_CRISIS) & $-16.97^{* * *}$ & 4.87 & 1.43 & 0.17 \\
D(OP) & 4.30 & 2.99 & -3.95 & 0.00 \\
CointEq(-1) & $-0.60^{* * *}$ & 0.15 & & \\
\hline
\end{tabular}

$*$, ** and ${ }^{* * *}$ indicate significance at the $10 \%, 5 \%$, and $1 \%$ levels respectively 
linking global economics and has acted as a critical enabler of trade, as an engine for growth, and a driver of economic development.

According to International Trade Administration (2020) and Ntuli (2017) have highlighted that ports and terminals in South Africa are regarded as the engine of its economic development. Further, the South African government has identified the sector as one of the sectors that will play a pivotal role in promoting growth and development in the economy of the country. Therefore, to achieve 2030 targets investing in the sector is critical and the interventions for maritime transport infrastructure should receive its importance.

Table 6 shows the residual diagnostic test of the trade model. The residuals are normally distributed as the null hypothesis is not rejected at 5 percent. The autocorrelation test suggests that there is no serial correlation among the variables. The heteroskedasticity test failed to reject the null hypothesis at 5 percent. The stability test, which shows the Ramsey RESET test model is correctly specified with evidence of the probability value of 0.07 percent, which is greater than the 5 percent level of significance.

\section{Conclusions and recommendations}

The purpose of the study was to examine the extent of the impact of maritime transport financing on total trade as a percentage of GDP in South Africa. The ARDL technique was employed to estimate the long and short-run relationship between the variables of interest. The Bound test confirmed the existence of a co-integration. The results show that maritime transport financing has a positive impact on total trade in South Africa in both long-run and short-run analysis, thus indicating the importance of investment in this sector. Therefore, increasing investment in maritime transport promotes total trade in South Africa.

Based on the results it is recommended that continuous investment in maritime transport, in particular in quality and sustainable infrastructure in the interests of improving the efficiency, effectiveness, and profitability of the country's trade. The public sector is also encouraged to formulate policies that have the potential to encourage foreign and private investment partnerships in the maritime industry. To be able to take advantage of the existing maritime transport system opportunities and benefits, and to increase the volume of trade, would require continuous improvement and maintenance of maritime infrastructure. This has the potential to boost the country's economic development and trade turnover.

The investment should also be able to support the local registry of vessels through incentives and encouraging the use of South African flagged ships for cargo and coastal operation which will be beneficial for the South African economy. In addition, local ship

Table 6 Diagnostic tests

\begin{tabular}{lc}
\hline Test & MTF and trade \\
\hline Autocorrelation & $3.14(0.735)$ \\
Heteroscedasticity & $1.640(0.190)$ \\
Normality & $1.471(0.471)$ \\
RESET test & $3.136(0.077)$ \\
\hline
\end{tabular}


owners should have access to contracts supported by sustainable and forward-driven legislations that will develop the competitiveness of local ship owning.

Government should also establish a South African flagged fleet for coastal and international shipping and also venture into a strategic collaboration with other major maritime nations to gain access to knowledge and expertise in shipping. Strengthening maritime education system in higher education institutions in order to create a pool of maritime experts and professionals so that they can lead and manage the maritime sector in South Africa. This can also be achieved by the establishment of collaboration with other maritime countries for the purpose of knowledge sharing and skills transfer.

The South African Government views the country's ports and terminals as key engines for economic growth. South Africa is situated on one of the busiest international sea routes, and critical to international maritime transportation, and its geographical location presents a huge opportunity for investing in a diversified maritime market. Therefore, creating container terminal capacity and inland deport in order to improve efficiency and productivity within existing port infrastructure and equipment. This will help the sector to be efficient in order to improve economic activities and promote economic growth. Hence the public sector should encourage private involvement in the sector in port operation which improves port development. Doing so would boost total trade and promote economic growth.

\title{
Limitation and future research
}

The main limitation of this study is data availability. For instance, the available data for maritime transport financing only covers the period of 1994 to 2019. In order to explore other research analysis, future research would also look at the impact of maritime transport financing on South Africa's economic growth or economic development.

\begin{abstract}
Abbreviations
ADF: Augmented Dickey-Fuller; ARDL: Autoregressive distribution lag; BTH: Tianjin Hebei; DEA: Development of Environment Affairs; EU: European Union; FDI: Foreign Direct Investment; GDP: Gross Domestic Product; GMM: Generalised method of moments; KMS: Kilometers; MTF: Maritime transport financing; NDP: National development plan; NGP: New growth path; NTMP: National transport masters plan; PMG: Pooled Mean Group; PP: Philip Perron; SDG: Sustainable development goal; SEM: Structural equation; SWOT: Strength weakness opportunities and threats; UNCTAD: United Nations Conference on Trade and Development; USD: United States Dollar.
\end{abstract}

Acknowledgements

We would like to thank the BAAP grant funding.

Authors' contributions

WM: conceptualization, design, acquisition of data, methodology, analysis, and interpretation of data. RN: revising the article and supervision. Both authors read and approved the final manuscript.

Funding

This study is funded by National Research Foundation (NRF) under the grant Black Academic Advancement Programme (BAAP). Grant No: 120625.

Availability of data and materials

Data is openly available on the Nation treasury (http://www.treasury.gov.za/documents/national\%20budget/default. aspx), World Bank (https://data.worldbank.org/) and Heritage Foundation (https://www.heritage.org/).

\section{Declarations}

Competing interests

There is a conflict of interest and the funders had no role in the design of the study, in the collection of data, analysis of data, in the writing of the manuscript, or decision to publish the results. 
Received: 11 November 2021 Accepted: 21 January 2022

Published online: 05 February 2022

\section{References}

Akbulaev N, Bayramli G (2020) Maritime transport and economic growth: Interconnection and influence (an example of the countries in the Caspian Sea coast; Russia, Azerbaijan, Turkmenistan, Kazakhstan, and Iran). Mar Policy 118:104005. https://doi.org/10.1016/j.marpol.2020.104005

Banister D, Berechman Y (2001) Transport investment and the promotion of economic growth. J Transp Geogr 9(3):209-218

Batra R, Beladi H (2013) The US trade deficit and the rate of interest. Rev Int Econ 21(4):614-626. https://doi.org/10.1111/ roie.12059

Bottasso A, Conti M, Ferrari C, Tei A (2014) Ports and regional development: a spatial analysis on a panel of European regions. Transp Res A Policy Pract 65:44-55

Bougheas S, Demetriades PO, Morgenroth ELW (1997) Infrastructure, transport costs, and trade. J Int Econ 47(169-189):1997

Breusch TS (1978) Testing for autocorrelation in dynamic linear models. Aust Econ Pap 17:334-355

Breusch TS, Pagan AR (1979) A simple test for heteroscedasticity and random coefficient variation. Econometrica 47:1287-1294

Chang YT, Shin SH, Lee PTW (2014) Economic impact of port sectors on South African economy: an input-output analysis. Transp Policy 35:333-340

Clark X, Dollar D, Micco A (2004) Port efficiency, maritime transport costs, and bilateral trade. NBER working paper no: 10353

Clark X, Dollar D, Micco A (2004) Port efficiency, maritime transport costs, and bilateral trade. National Bureau of Economic Research

Deng P, Lu S, Xiao H (2013) Evaluation of the relevance measure between ports and regional economy using structural equation modeling. Trans Policy 27:123-133

Department of Environmental Affairs (DEA) (2019) Operation Phakisa-Oceans economy. https://www.environment.gov. za/projectsprogrammes/operationphakisa/oceanseconmy. 21 Nov 2019

Depken CA, Sonora RJ (2005) Asymmetric effects of economic freedom on international trade flows. Int J Bus Econ 4(141-155):2005

Dickey DA, Fuller WA (1981) Likelihood ratio statistics for autoregressive time series with a unit root. Econometrica 49:1057-1072

Edwards L, Schoer V (2002) Measures of Competitiveness: a dynamic approach to South Africa's trade performance in the 1990S. S Afr J Econ 70(6):1008-1046. https://doi.org/10.1111/j.1813-6982.2002.tb00055.x

Elliott G, Rothenberg TJ, Stock J (1996) Efficient tests for an autoregressive unit root. Econometrica 64:813-836

Engen E, Hubbard G (2004) Federal government debt and interest rates. NBER reporter, p 15

Falvey R (1976) Transport costs in the pure theory of international trade. Econ J 86(343):536-550

Fedorenko R, Yakhneeva I, Zaychikova N, Lipinsky D (2021) Evaluating the socio-economic factors impacting foreign trade development in port areas. Sustainability 13:8447. https://doi.org/10.3390/su1315844

Ferrari C, Percoco M, Tedeschi A (2010) Ports and local development: evidence from Italy. Int J Transp Econ 37(1):9-30

Fratila A, Gavril IA, Nita SC, Hrebenciuc A (2021) The importance of maritime transport for economic growth in the European Union: a panel data analysis. Sustainability 2021(13):7961. https://doi.org/10.3390/su13147961

Funke N, Claassen M, Nortje K, Meissner RA (2016) Research, innovation and knowledge management road map for the South African Maritime Sector. CSIR

Gani A (2017) The logistics performance effect in international trade. Asian J Ship Log 33(4):279-288. https://doi.org/10. 1016/j.ajsl.2017

Godfrey LG (1978) Testing against general autoregressive and moving average error models when the regressors include lagged dependent variables. Econometric 46:1293-1301

Gordon JR, Lee PM, Lucas HC (2005) A resource-based view of competitive advantage at the port of Singapore. J Strategy Inf Syst 14(1):69-86

Han F, Wang D, Bo Li B (2019) Spillover effects of ports and logistics development on economic power: evidence from the Chinese BTH regions. Sustainability 11:4316. https://doi.org/10.3390/su11164316

Hargono S, Sutomo S, Alisyahbana J (2013) The influence of the port on the economic growth of Batam Island. Procedia Environ Sci 2013(17):795-804

Hausman WH, Lee HL, Subramanian U (2013) The impact of logistics performance on trade. Prod Oper Manag 22(2):236-252

Helble M (2014) The Pacific's connectivity and its trade implications. Asian Development Bank Institute working paper 499. https://doi.org/10.1186/s41072-018-0027-0

Igberi CO, Ogunniyi MB (2013) Has the maritime transport sector impacted the growth of Nigeria's Economy? J Bus Econ 4(8):722-736

International Monetary Fund (2016)

International Trade Administration (2020) South Africa country commercial guide. https://www.trade.gov/knowledgeproduct/south-africa-port-and-logistics. U.S Department of Commerce. Accessed on 12 Apr 2021

Ismail NW, Mahyideen JM (2015) The impact of infrastructure on trade and economic growth in selected economies in Asia. ADBI working paper 553. Tokyo: Asian Development Bank Institute. http://www.adb.org/publications/impactinfrastructuretrade-and-economic-growth-selected-economies-asia/

Jarque CM, Bera AK (1980) Efficient tests for normality, homoscedasticity, and serial independence of regression residuals. Econ Lett 6(255-259):1980 
Jiang N (2010) Seaport investment and economic development in China. Dalian Marine University Press, Dalian Jouili TA, Allouche MA (2016) Impacts of seaport investment on economic growth. Promet Traffic Transp 28(4):365-370 Kazutomo A, Wilson JS (2019) Investing in port infrastructure to lower trade costs in East Asia. Policy research working paper 4911

Lakshmanan T (2011) The broader economic consequences of transport infrastructure investments. J Transp Geogr 19(1):1-12

Limao N, Venable AJ (2001) Infrastructure, geographic disadvantages, and transport cost. Policy research working paper 2257

Lloyd C, Onyeabor E, Nwafor N, Alozie OJ, Nwafor M, Mahakweabba U, Adibe E (2020) Maritime transportation and the Nigerian economy: matters arising. Commonwealth. https://doi.org/10.1080/03050718.2019.1708426

Loon CK (2009) Short-sea transport, and economic development in Penang. Bus Intell J 2(2):2009

Morapedi K, Makhhari M (2017) National transport master plan (NATMAP) 2050. Department of Transport

Mudronja G, Jugovic A, Skalamera-Alilovic D (2020) Seaports and economic growth: panel data analysis of EU port regions. J Mar Sci Eng 8:1017. https://doi.org/10.3390/jmse8121017

Munim ZH, Schramm HJ (2018) The impacts of port infrastructure and logistics performance on economic growth: the mediating role of seaborne trade:1. https://doi.org/10.1186/s41072-018-0027-0

Nordas H, Piermartini R (2004) Infrastructure and trade. Staff working paper, Economics Research and Statistics Division, WTO

Ntuli D (2017) Comprehensive maritime transport policy for South Africa. Department of transport

Park JS, Seo YJ (2016) The impact of seaports on the regional economies in South Korea: panel evidence from the augmented Solow model. Transp Res E Log 85:107-119

Operation Phakisa (2015) Unlocking the economic potential of South Africa's Oceans. Department of Agriculture, Forestry \& Fisheries. Annual report

Phillips PC, Perron P (1988) Testing for a unit root in time series regression. Biometrika 75:335-346

Portugal-Perez A, Wilson JS (2012) Export performance and trade facilitation reform: hard and soft infrastructure. World Dev 40(7):1295-1307

Qiongzhi L, Qi (2011) Corruption erosion and financial expenditure distortion. Finance Trade Res 22:59-64

Ramsey JB (1969) Tests for specification errors in classical linear least-squares regression analysis. J R Stat Soc Ser B (methodol) 31:350-371

Rehman FU, Noman AA, Ding Y (2020) Does infrastructure increase exports and reduce trade deficit? Evidence from selected South Asian countries using a new Global Infrastructure Index. https://doi.org/10.1186/s40008-020-0183-x

Rodrigue JP (2020) The geography of transport systems. Routledge, New York

Sakyi D, Immurana M (2021) Seaport efficiency and the trade balance in Africa. Maritime Transp Res 2:100026

Shi W, Li KX (2016) Themes and tools of maritime transport research during 2000-2014. Marit Policy Manag 44(2):151169. https://doi.org/10.1080/03088839.2016.1274833

Shi W, Li KX (2017) Themes and tools of maritime transport research during 2000-2014. Marit Policy Manag 44(2):151169. https://doi.org/10.1080/03088839.2016.1274833

Song L, van Geenhuizen M (2014) Port infrastructure investment and regional economic growth in China: Panel evidence in port regions and provinces. Transp Policy 36:173-183

Stopford M (1997) Maritime transport, 3rd edn. Routledge, New York

Taku Fundira (2011) South Africa; economic and trade policy overview. Trade Law Center

Tayebi S, Gholami P, Rashidi R, Rameshi S (2015) The impact of oil maritime transport growth on economic growth in Iran. In: 2nd international conference on new research in management, economics and accounting. https://civilica.com/ doc/440059

National Treasury (1999) Medium term budget policy statement. South African Government, Pretoria

National Treasury (2011) Budgetary statement 2011. Government Printers, Pretoria

National Treasury (2017) Budgetary statement 2017. Government Printers, Pretoria

UNCTAD (2019) Review of maritime transport 2019. United Nations publications. Sales, No. E.19 IID.20. New York and Geneva

Veitch C (2017) South African Maritime transport and Marine manufacturing sector. African Business Information. https:// www.whoownswhom.co.za/store/info/4509? segment=South+African+Maritime+Transport+and+Marine+ Manufacturing+Sector. Accessed on 03 Feb 2021

Walker D (2018) Will Operation Phakisa deliver prosperity? https://issafrica.org/isstoday/avoiding-the-sirens-song-willoperation-phakisa-deliver-prosperity. Accessed 12 Jan 2021

World Economic Forum (2015) Methodology: the 12 pillars of competitiveness. http://reports.weforum.org/globalcompetitiveness-report-2014-2015/methodology/. Accessed on 12 Feb 2021

World Trade Organisation (2019) World trade statistical review 2019

Yeaple S, Golub S (2002) International productivity differences, infrastructure, and comparative advantage. Mimeo. http:// www.econ.yale.edu/seminars/trade/tdw02/yeaple-021216.pdf. Accessed 2 Feb 2007

Yeo GT, Roe M, Dinwoodie J (2008) Evaluating the competitiveness of container ports in Korea and China. Trans Res Part A Policy Pract 42:910-921. https://doi.org/10.1016/j.tra.2008.01.014

\section{Publisher's Note}

Springer Nature remains neutral with regard to jurisdictional claims in published maps and institutional affiliations. 